\title{
LOSS OF INFECTIVITY OF POLIOVIRUS 1 IN RIVER WATER UNDER SIMULATED FIELD CONDITIONS
}

\author{
C P Cubbage, J J Gannon*, K W Cochrant and G W Williams $\ddagger$ \\ Departments of Environmental and Industrial Health*, Epidemılogy† and Biostatısticsł. \\ School of Public Health, University of Michigan, Ann Arbor, Michigan 48109, U S A
}

(Recesved 13 March 1979)

\begin{abstract}
The effects of light, virus concentration, and turbidity on the rate of loss of infectivity (LOI) of poliovirus 1 were investigated in two test systems, which utılized flowing river water Two levels of each variable were used in a $2^{3}$ confounded factorial design The seeded systems were sampled at regular intervals to establish LOI rates Virus infectivity was measured by plaque assay Loss of infectivity followed a two-component curve, an initial, rapid phase followed by a second, slower component The slopes of the two components were examined by the analysis of variance to determine the potential influence of each variable Both light and turbidity exerted a significant influence on the LOI rate in the second component of the LOI curve and also in the transition period between the two components, however, during the initial rapid phase none of the variables influenced the LOI rate (at the 005 significance level) This research demonstrates the significance of light as a virucidal component in the aquatic environment
\end{abstract}

\section{INTRODUCTION}

Initial work on the waterborne transmission of enteric viruses has been directed at the detection and enumeration of viral contaminants in sewage effluents and receiving waters (Akın et al, 1971) More recently, attention has been directed toward the behavior of enteric viruses in the aquatic environment (Berg, 1976, Berg, 1977, Carlson et al, 1968, Floyd \& Sharp, 1977, Gerba \& Schaiberger, 1975a, Schaiberger, (975b)

Current wastewater treatment techniques do not completely remove viral hazards from the effluents of treatment faclities (Berg, 1976, Berg, 1977) The continuing association of enteric viruses with a number of human diseases points up the lack of epidemiological evidence to establish the extent of the viral hazard in our potable water supplies (DeMichele, 1974) Increasing reliance on recycled water will accelerate the need to understand the factors which influence the survival of these viruses in water

The purpose of this study is to evaluate the influence of two variables known to affect virus behav1or in the aquatic environment, turbidity (Bitton, 1975) and virus concentration (Akın et al 1971), and a third variable, light (ambient solar radiation), which has not been previously examined for its effect on viruses in the aquatic environment

\section{MATERIALS AND METHODS}

\section{Experimental facilities}

Two recirculating flow systems were used (Figs 1 and 2) The tray system consisted of four plastic trays $(46 \times 27 \times 45 \mathrm{~cm})$ fitted with pumps which recirculated the 551 capacity approximately 11 times in
$10 \mathrm{~min}$ The trays were placed in a water bath for temperature control

The experimental channel system was a recirculating artificial stream constructed from four-foot aluminium sections lined with $15 \mathrm{mil}$ vinyl to form two parallel channels $2146 \mathrm{~m}$ long and $15 \mathrm{~cm}$ deep Each channel was approximately $18 \mathrm{~cm}$ wide Including the recirculating hardware the system capacity was 30001 A more complete description of the channel facility has been publıshed (Gannon et al, 1966)

\section{Light}

The tray experıments were conducted in June 1975 Solar intensity was recorded on a pyrheliometer using an arbitrary scale to provide relative values for comparing experimental blocks of tray data Except for a $5 \mathrm{~h}$ period of heavy rain, the daylight hours were typified by full sun and occasional scattered clouds. The temperature of the water in both dark and ambient trays ranged from 16 to $235^{\circ} \mathrm{C}$ with a mean of $187^{\circ} \mathrm{C}$ There did not appear to be a significant difference between the light (ambient) and dark tray temperatures

\section{Turbidity}

Turbidity was measured as nephelometric turbidity units (NTU) Natural turbidity was less than 25 NTU and was used as the low level High level turbidity was provided by raising the turbidity to 36 NTU with a stock solution of organically loaded bentonite The bentonite stock solution was prepared in 3\% beef broth, then centrifuged and resuspended three tımes in autoclaved river water to remove excess dissolved beef broth Prelımınary work comparing virus, recovery from river water, with river water plus bentonite showed a slight recovery reduction from the river water plus bentonite 

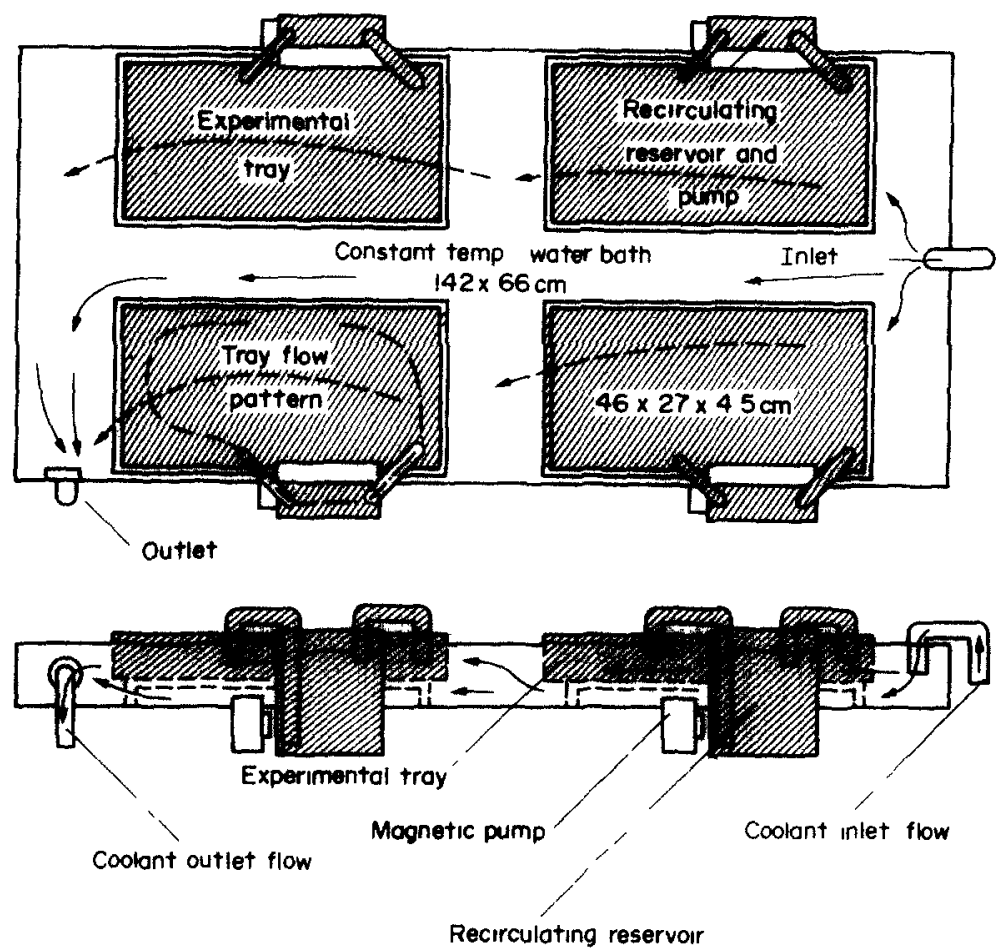

Tray and reservoir capacity $=551$

Pump flow flow rate $=225 \mathrm{I} \mathrm{h}^{-1}$

Fig 1 Experımental tıay system recirculdung flow pattern

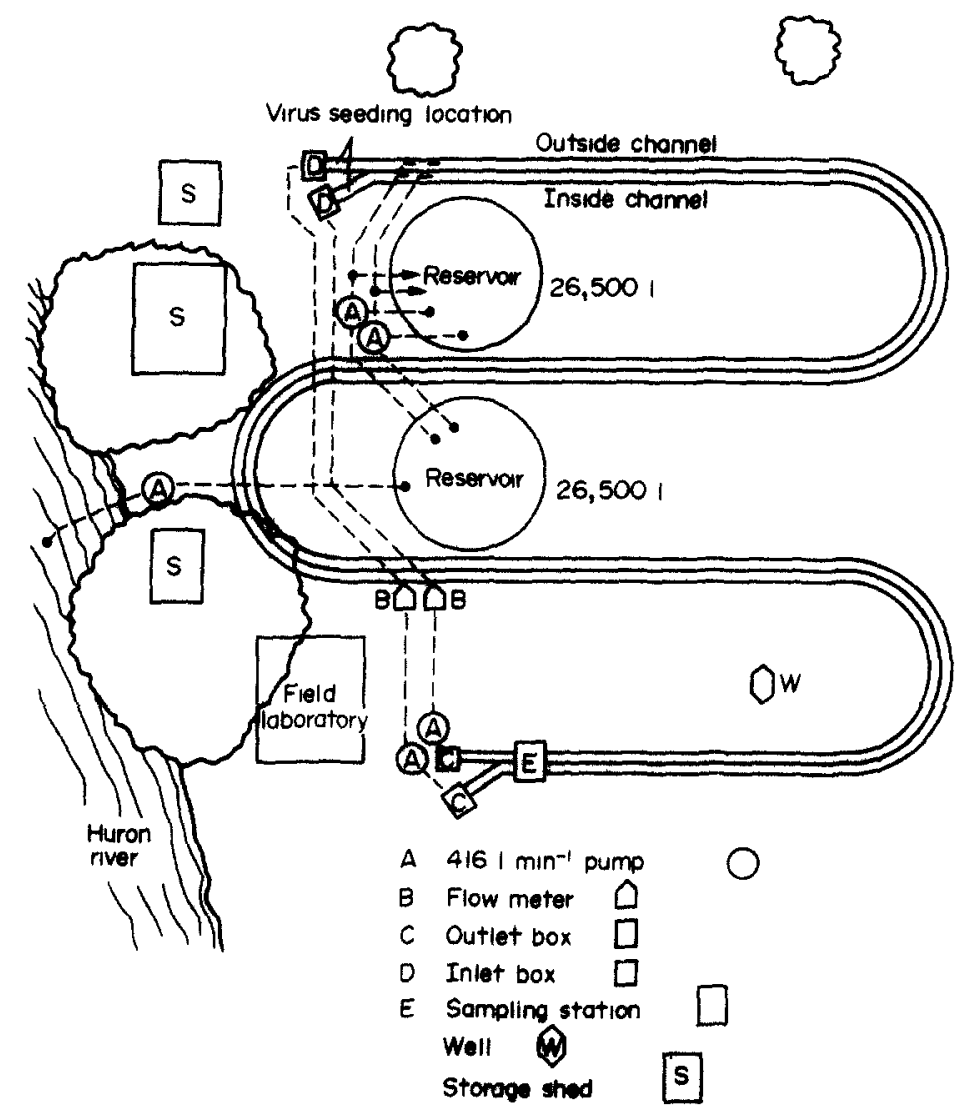

Fig 2 Experimental channel system 


\section{Virus concentration levels}

The high and low starting virus levels in the tray study were approximately $10^{5}$ and $10^{4} \mathrm{PFU} \mathrm{ml}^{-1}$, ro spectıvely In the channel experıments, the startıng levels ranged from 700 to $4200 \mathrm{PFU} \mathrm{ml}^{-1}$

\section{Experimental design and analysis}

The basic statıstıc used to evaluate the influence of each variable and potential variable interactions was the loss of infectivity (LOI) rate The virus concentration of each sample was plotted against time and the LOI curves were determined by employing the least squares method of curve fittıng The LOI curve was assumed to be of the form

$$
y=a \mathrm{e}^{b x}
$$

This equation may be linearized into

where

$$
\ln y=\ln a+b r
$$

$$
\begin{aligned}
& y=\text { the number of PFU ml } \\
& \quad \text { water at tıme }=x \mathrm{~h} \\
& b=\text { the rate of LOI, and } \\
& x=\text { the time elapsed in hours }
\end{aligned}
$$

The experimental tray design utılized each variable at two levels All possible combinations of three variables at two levels were used twice during the 16 experımental units The units were organized into four blocks which were conducted on alternate weeks to allow prompt dssay of the virus-seeded river water The specific block design (of high and low variable levels) presented in Table 1 strengthened the analysis of the potential effects of each variable and two-var1able interactions at the expense of information on three-factor interaction, the latter being confounded with the block effects

Three channel experments were conducted with similar variable levels to examine the potential of the facility for LOI studies

\section{Sampling intervals}

The LOI rates were calculated from virus assays at zero, $025,1,6,12 \mathrm{~h}$ and each $12 \mathrm{~h}$ interval thereafter All values were based on the sample assay of the seeded water except the zero hour data which were calculated from the viral assay of the stock virus inoculum and the dilution values of the tray volumes The first tray samples were taken after the mixıng period $(15 \mathrm{~min})$

\section{Water source}

For the channel experiments, water was pumped directly from the adjacent Huron River into 26,500 1 reservoirs for mixing to provide a homogeneous supply For the tray experıments, river water was collected and stored in a 7501 carboy for a common source Conductivity, $\mathrm{pH}$ and nutrient data were obtained prior to each set of experiments to establish the uniformity between experiments

\section{Virus preparation}

Culture of cells and virus Poliovirus 1 (vaccine strain LSc2ab) was propagated in Vero cells (ATCC CCL81) in 05 gallon roller bottles Vero cells were also used to dssay virus in the channel study, as de-

Table 1 LOI slope statistics for the first and second components at selected intervals

\begin{tabular}{lccccc}
\hline $\begin{array}{l}\text { Experimental } \\
\text { tray* }\end{array}$ & $\begin{array}{c}\text { High level } \\
\text { variables }\end{array}$ & $0-1 \mathrm{~h}$ & $0-6 \mathrm{~h}$ & $1-72 \mathrm{~h}$ & $6-72 \mathrm{~h}$ \\
\hline BItlt & L & -149 & -073 & -017 & -012 \\
BIt2 & V & -137 & -076 & -010 & -008 \\
BIt3 & TLV & -145 & -073 & -018 & -015 \\
BIt4 & T & -154 & -072 & -009 & -006 \\
BIIt1 & No high levels & -160 & -082 & -011 & -007 \\
BIIt2 & TV & -151 & -082 & -009 & -007 \\
BIIt3 & TL & -156 & -082 & -024 & -015 \\
BIIt4 & LV & -161 & -082 & -032 & -025 \\
BIIIt1 & T & -159 & -079 & -009 & -006 \\
BIIIt2 & V & -153 & -077 & -010 & -008 \\
BIIIt3 & TLV & -153 & -079 & -019 & -014 \\
BIIIt4 & L & -148 & -083 & -031 & -023 \\
BIVt1 & No high levels & -131 & -073 & -014 & -010 \\
BIVt2 & TV & -126 & -072 & -009 & -007 \\
BIVt3 & TL & -123 & -068 & -023 & -014 \\
BIVt4 & LV & -124 & -076 & -032 & -025 \\
\hline
\end{tabular}

$\uparrow$ B-block, t-tray

$\ddagger T=$ turbidity, $\mathrm{L}=$ lıght, $\mathrm{V}=$ virus

High turbidity $>30$ NTU

Low turbidity $<25$ NTU

High light-ambient solar radiation

Low light--total exclusion

High virus $-110,000-130,000 \mathrm{PFU} \mathrm{ml}^{-1}$ starting at tıme 0

Low virus-11,000-13,000 PFU ml ${ }^{-1}$ startıng at time 0 
scribed below The Vero cells were grown MEM in Hanks' balanced salt solution (HBSS) with $10_{, 0}^{\circ}$ fetal calf serum and an antibiotic supplement consisting of 100 units penicillin $\mathrm{G} 100 \mu \mathrm{g}$ streptomycin $100 \mu \mathrm{g}$ kanamycin and $4 \mu \mathrm{g}$ amphotericin B per $\mathrm{ml}$ For virus preparation roller bottle monolayers were rinsed three tımes with $10 \mathrm{ml}$ of HBSS and each bottle then inoculated with $5 \mathrm{ml}$ of undiluted dye-free stock virus and $25 \mathrm{ml}$ of serum-free, dye-free MEM When cultures showed advanced cytopathology, bottles were frozen and thawed three tımes Cellular debris was removed by centrifugation at $300 \mathrm{~g}$ for $20 \mathrm{~min}$ Pooled supernatant fluid was stored at $-20^{\circ} \mathrm{C}$ until used

\section{Virus assay}

BGM cells were used to assay virus in the tray study BGM cells were grown in MEM with $10 \%$ fetal call serum, and $5 \mu \mathrm{g} \mathrm{ml}^{-1}$ of gentamicin and amphotericin B, subcultured as described by Dahling et al (1974) For maintenance, serum concentration was reduced to $5 \%$ and penicillın-streptomycin (100 units and $100 \mu \mathrm{g} \mathrm{ml}^{-1}$ ) substituted for gentamicin Levels of infectious virus in water were determined by plaque assdy (Melnıck \& Wenner, 1969) using two-ounce prescription bottles The overlay medium consisted of $15 \%$ Bacto-Agar (Difco, Inc) in MEM $2 \%$ hedt inactivated fetal calf serum, five-fold concentrate of the antibiotic supplement described above $0005^{\circ}$ \% neutral red and $25 \mathrm{mM} \mathrm{MgCl}{ }_{2}$ Cultures were examIned daly after $48 \mathrm{~h}$ (for a total of 7 days) and all plaques marked and recorded Data were recorded ds plaque forming units (PFU) per $\mathrm{ml}$

\section{Virus concentrating technique}

For the channel experiments the membrane filter process described by Wallis et al, (1972) was modified to allow rapid handling of the more turbid samples The ease of manıpulation, minımal tıme requirements and sterile concentrate provided by the technique were the bdsic factors considered in selecting the process To the $250 \mathrm{ml}$ sample, $2 \mathrm{ml}$ of $01 \%$ methyl orange was added as a $\mathrm{pH}$ indicator The sample was then acidified to approximately $\mathrm{pH} 4$ with $1 \mathrm{~N} \mathrm{HCl}$ Following deidification $2 \mathrm{ml}$ of $005 \mathrm{M} \mathrm{AlCl}$ and $10 \mathrm{ml}$ of $125^{\circ}$ \% celite (Hill et al, 1974b) were added to the sample and thoroughly mixed The sample was then vacuum filtered through a combination of two $47 \mathrm{~mm}$ diameter filters as a single unit, an AP25 fiberglass prefilter followed by an $045 \mu \mathrm{m}$ membrane filter The fiberglass prefilters were pretreated with a $1 \%$ Tween 80 solution followed by a thorough rinse with distılled water to minimize virus adsorption to the fibergldss The river water was vacuum filtered to adsorb the virus content of the sample onto the membrane filter A sterile test tube was aseptically placed beneath the filter base and the sample was eluted through the filters with $45 \mathrm{ml}$ of $005 \mathrm{M}$ glycine- $\mathrm{NaOH}$ buffer at $\mathrm{pH} 115 \mathrm{An}$ additional $45 \mathrm{ml}$ of $005 \mathrm{M}$ glycine- $\mathrm{HCl}$ bufier at $\mathrm{pH} 20$ was passed through the filter to neutralize the concentrated sample The $9 \mathrm{ml}$ of eluate was transferred into a sterle screw-capped test tube containing $1 \mathrm{ml}$ of a 10 -fold concentrate of HBSS and 50-fold concentrate ol standard antibiotics The sample volume had thus been reduced from $250 \mathrm{ml}$ to $10 \mathrm{ml}$ and was rendered isotonıc for tissue culture application Any bacterial contamination which may have occurred at the field station was suppressed by the inclusion of antibiotics in the concentrated sample Preliminary tests for recovery efficiency utilized $250 \mathrm{ml}$ of river water seeded with 2066 PFUs per $10 \mathrm{ml}$ and resulted in a $426^{\circ}$ 。 recovery rate No concentration or clarification techniques were necessary dt the virus levels used for the tray study Samples were assayed immediately or stored at $4 \mathrm{C}$ for no longer than $12 \mathrm{~h}$

\section{RESULTS}

\section{Tray experiments}

The plotted data points appeared to fit a two stage LOI curve pattern which has been previously observed (Akın et al, 1971, Hiatt, 1964, Malina et al, 1975) Figures 3-10 contan the curves of replcated experimental units, averaged for more convenient presentation The curves illustrate the virus inocula levels used, duration of LOI, and the pattern of two component slopes Several time intervals were examined to determine the most representative two component curves Table 1 presents the slopes of the various LOI component intervals The transition or breakpoint between the more rapid, early LOI slope and the slower final LOI slope occurred during the

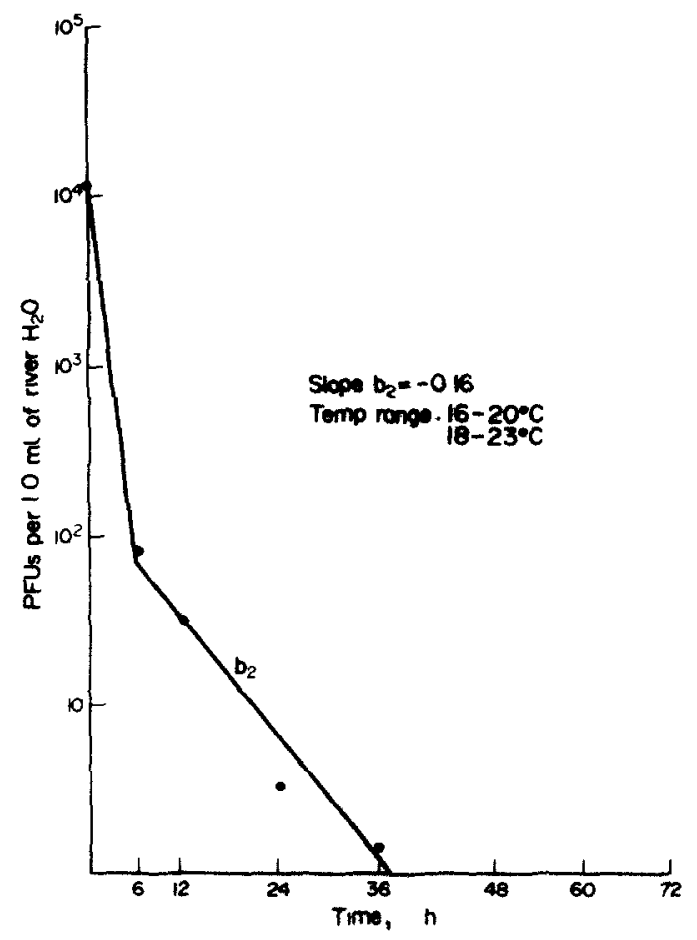

Fig. 3 A verage tray loss of infectivity BItl and BIIIt4 (low turbidity, high light, low virus) 


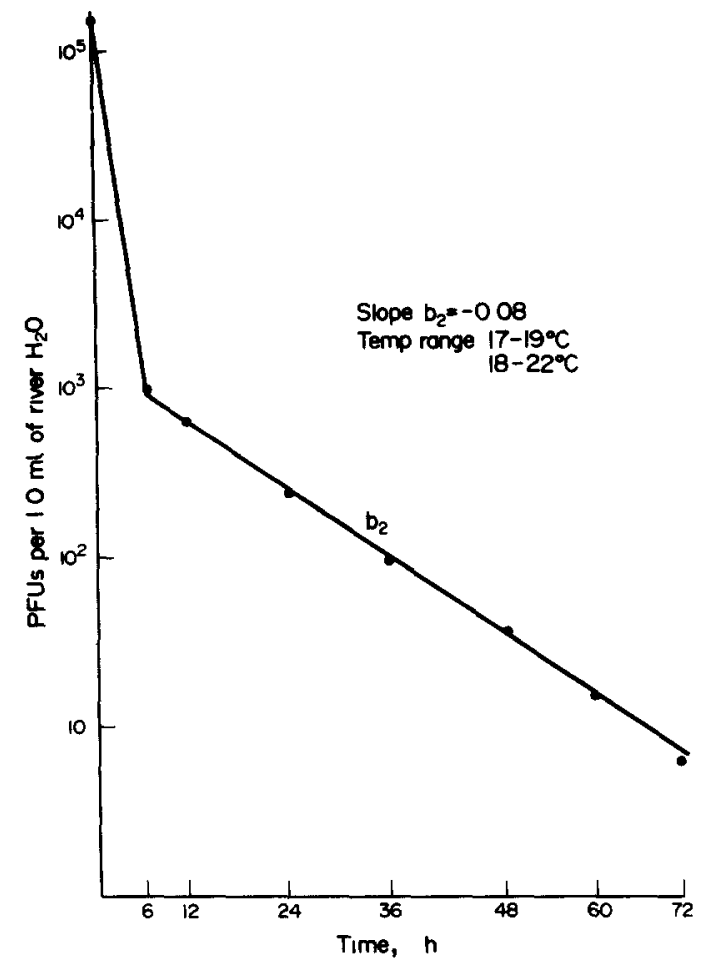

Fig 4 A verage tray loss of infectivity BIt2 and BIIIt2 (low turbidity, low light, high virus)

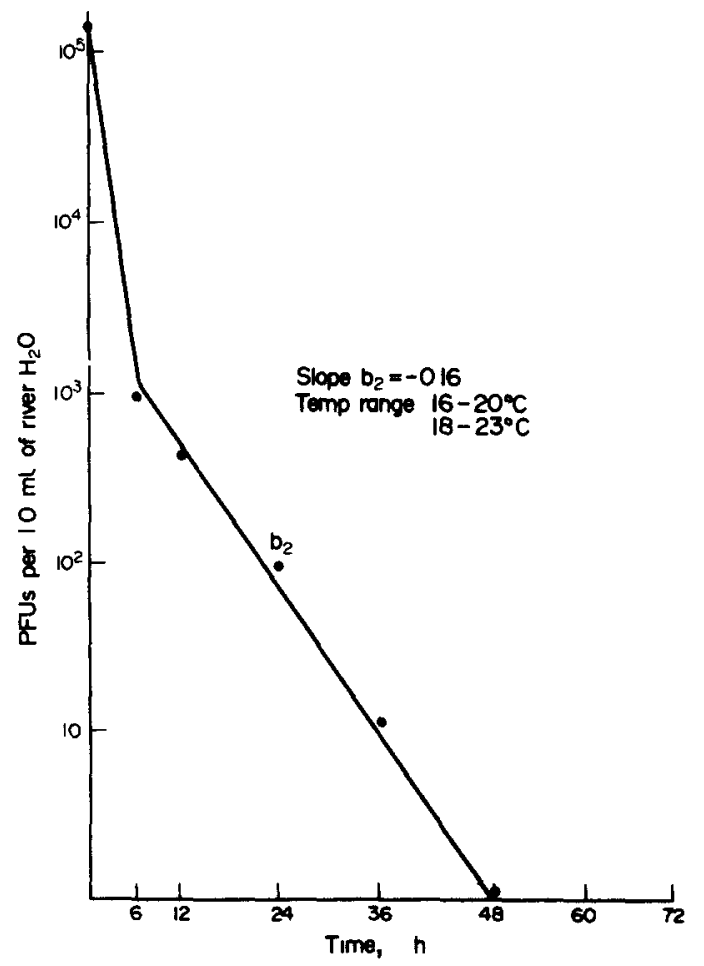

Fig 5 Average tray loss of infectivity BIt3 and BIIIt3 (high turbidity, high light, high virus)

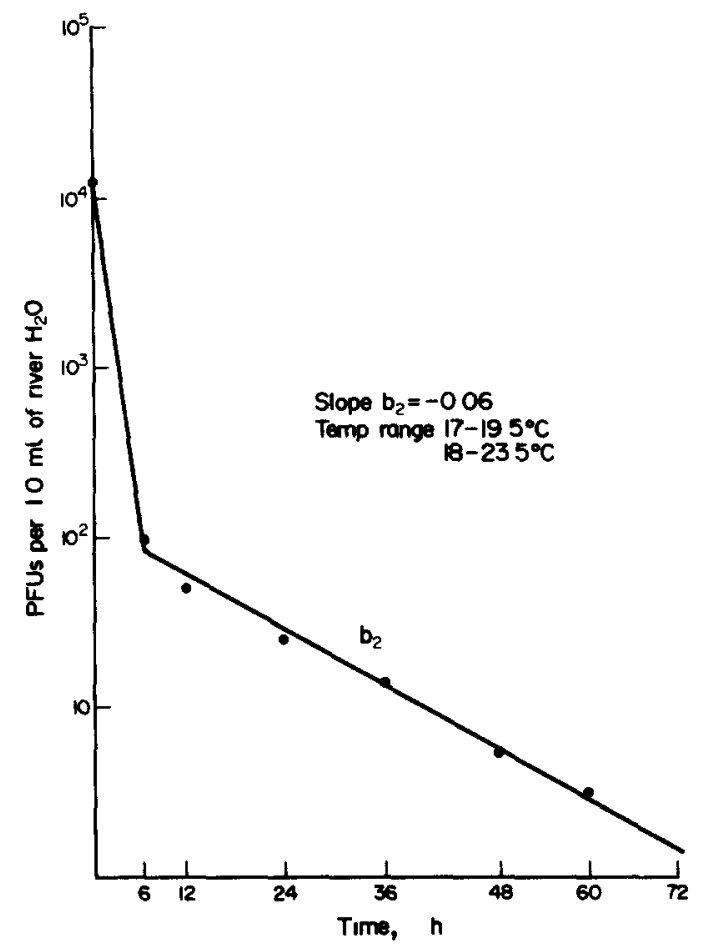

Fig 6 Average tray loss of infectivity BIt4 and BIIIt (high turbidity, low light, low virus)

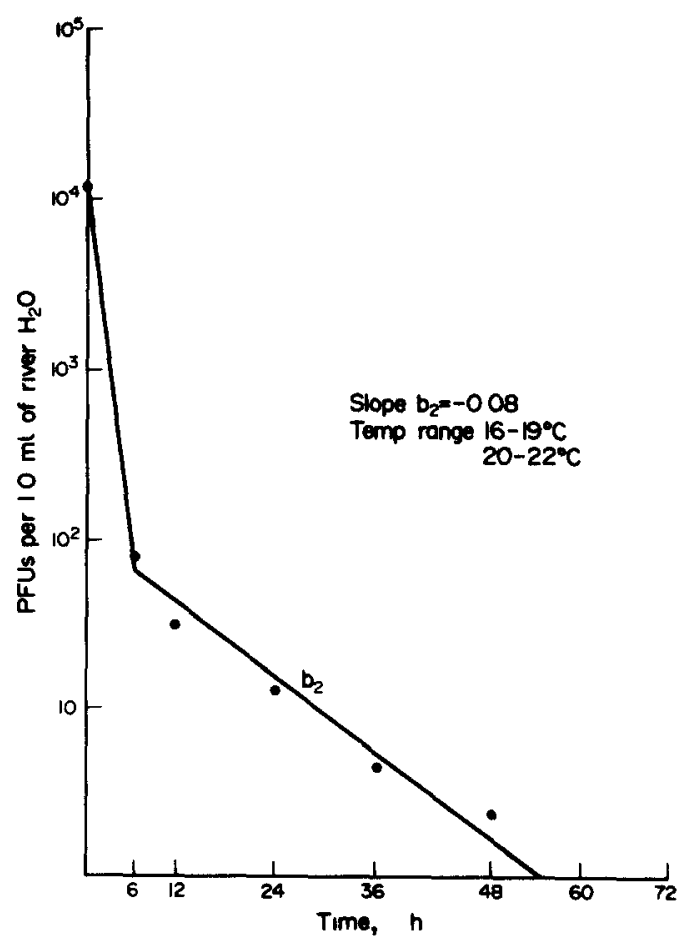

Fig. 7 Average tray loss of infectıvity Bilt1 and BIVil (low turbidity, low hight, low viris). 


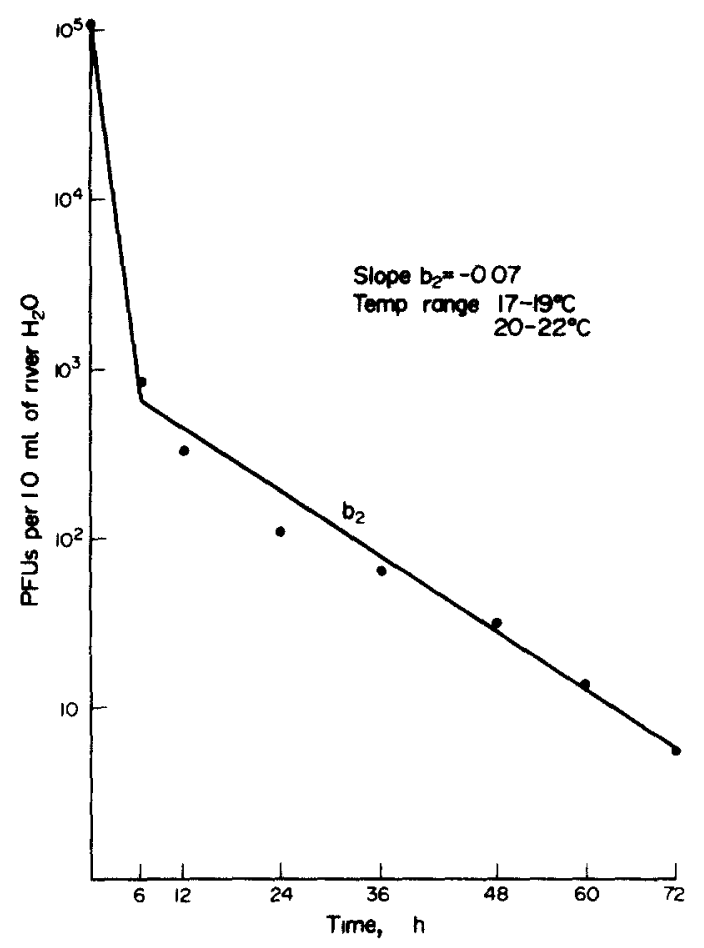

Fig 8 Average tray loss of infectivity BIIt2 and BIVt2 (high turbidity, low light, high virus)

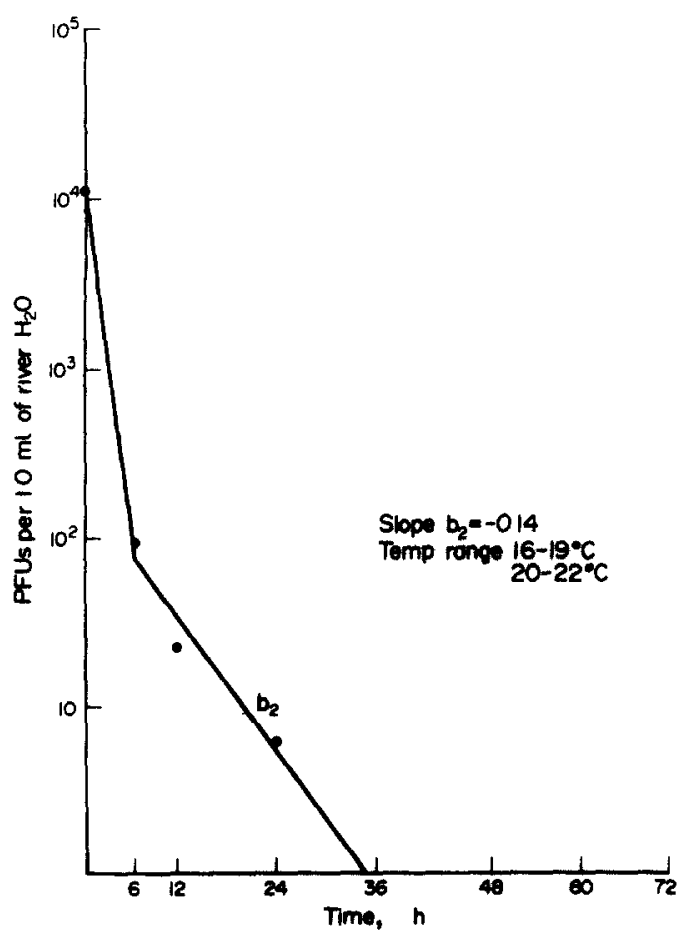

Fig 9 Average tray loss of infectivity BIIt3 and BIVt3 (high turbidity, high light, low virus) 1-6h interval No data were avallable from withın this interval so slope statistics were developed using both the $1 \mathrm{~h}$ point and the $6 \mathrm{~h}$ point as the breakpoint The amount of variability in the slope statistics was less for the second component when the breakpoint was arbitrarily placed at the $6 \mathrm{~h}$ point so it was used throughout as a matter of convenience

Analysis of variance

Both light and turbidity were indicated as sources of variation which affected the LOI rate during the second component $(6-72 \mathrm{~h})$ and the interval expanded to include the transition period $(1-72$ h) The $F$ values for turbidity derived from the analysis of variance, exceeded the critical $F$ value at the 005 significance level for both of the noted intervals The $F$ values for light were even more significant during the same intervals and exceeded the critical $F$ values at the 001 level Table 2 contans the calculated $F$ values None of the variables nor variable interactions were implicated as statistically significant sources of LOI rate variation during either of the intervals used as potential early LOI components $(0-1 \mathrm{~h}$ and $0-6 \mathrm{~h})$

\section{Channel experiments}

The LOI curves developed for the channel exper1ments also exhibited the two component curve pattern observed in the tray study Table 3 presents the slope statistics, including run 3 which utilized both channel and tray facilities conducted with parallel variable levels

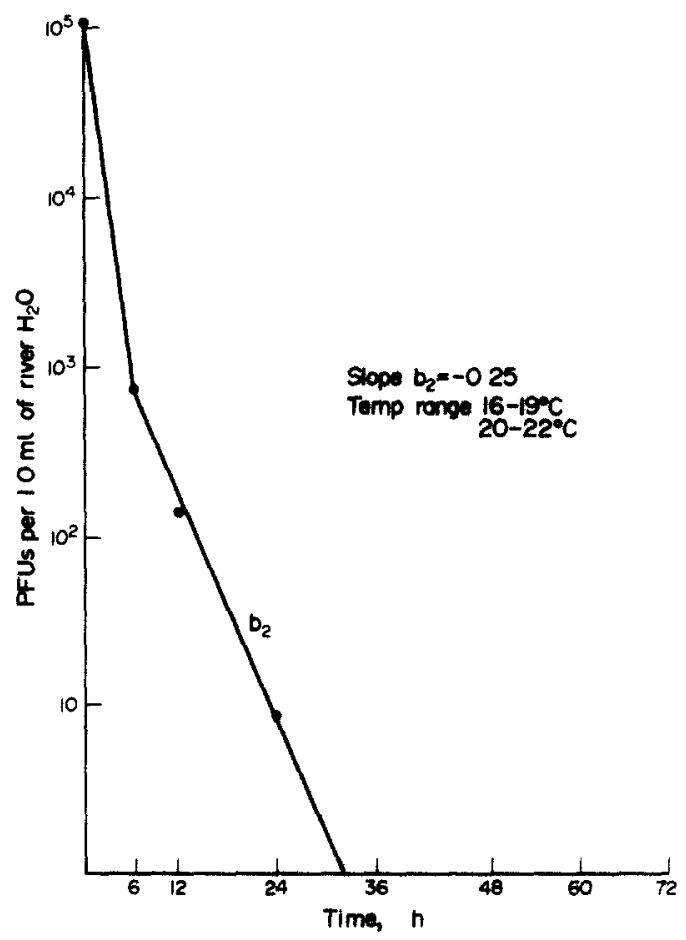

Fig 10 Average tray loss of infectivity BIIt4 and BIVi4 (low turbidity, high light, high virus) 
Table $2 F$ values for variables and variable interactions for tray experiments

\begin{tabular}{lcc}
\hline Source of Variation & $\begin{array}{c}F \text { Value } \\
(6-72 \mathrm{~h})\end{array}$ & $\begin{array}{c}F \text { Value } \\
(1-72 \mathrm{~h})\end{array}$ \\
\hline Turbidity & $818^{*}$ & $686^{*}$ \\
Light & $4992 \dagger$ & $6623+$ \\
Turbidity and light & 283 & 181 \\
Virus & 181 & 001 \\
Turbidity and virus & 102 & 221 \\
Light and virus & 139 & 061 \\
Replications $\ddagger$ & 102 & 145 \\
Blocks within replications & 137 & 283 \\
\hline
\end{tabular}

- Exceeds the critical $F$ value at the 005 significance level

+ Exceeds the critical $F$ value at the 001 significance level

¥ The $F$ value for "replications" indicates the extent of variation between experimental units which duplicate each other (BI and BIII, BII and BIV) See variable levels. Table I (Remington \& Shork, 1970)

Figure 11 demonstrates the poor curve fit for the channel experiments when the data for the zero to six hour interval are used for the initial curve component.

\section{Discussion}

The statistical analysis of the tray data did not identify the starting virus concentration as a significant factor in the determination of the rate of loss of infectivity (LOI) However, both turbidity and light were implicated as significant sources of variability

While the initial virus concentration was not significant (at the 005 level) for the rate of LOI, an interesting difference in the duration of the early LOI components was noted between the channel tray curves Differences between the two facilities rule out a definitive statement, but the lower starting virus levels used in the channel experiments (700-4200 PFU ml-1 of river water) may have played a role in the reduction of duration of the early LOI curve component (Akın et al, 1971) Any such inference from the current study must be regarded as speculative, however, the low virus levels used in the tray study and the levels of the channel inocula were of the same order of magnitude as those reported by others when a similar reduction in the duration of the early LOI component was noted, and suggested that the virus level affected the duration of the initial phase (Akın et al, 1971)

It has been pointed out that two phenomena account for the reduction in the levels of infectivity observed in enteric viruses in the aquatic environment, actual loss of infectivity brought about by impairment of the infective capability of the virus particle, and/or the apparent loss of infectivity which results from conditions that cause infectious particles to join together into clumps (which act as a single infectious focus) (Akin et al, 1971, Floyd et al, 1977, Gerba \& Schaiberger, 1975a, Scharberger, 1975b, Hill et al, 1974a, Moore et al, 1975, Schaub et al, 1974, Young \& Sharp, 1977)

The apparent LOI has been divided into situations that involve (1) the adsorption of virus particles onto other particulate matter in intımate contact with the water, and (2) the aggregation of virus particles into virus clumps (Akın et al, 1971, Bitton, 1975, Carlson et al, 1968, Fowlks, 1959, Floyd \& Sharp, 1977, Gerba \& Shabberger, 1975a, Hill et al, 1974b) Ionic

Table 3 Channel experıments LOI slope statıstics

\begin{tabular}{|c|c|c|c|c|}
\hline \multirow[b]{2}{*}{ Experımental unit } & \multirow[b]{2}{*}{ Experimental conditions } & \multicolumn{3}{|c|}{$(0-1 \mathrm{~h}) \quad \begin{array}{l}\text { Interval } \\
(1-\text { last h) }\end{array}$} \\
\hline & & Slope & Slope & $r^{2 *}$ \\
\hline \multicolumn{5}{|l|}{ Run I } \\
\hline channel I & $\begin{array}{l}\text { Low turbidity, low light } \\
\text { and low virus }\end{array}$ & -153 & -018 & 096 \\
\hline channel 0 & $\begin{array}{l}\text { High turbidity, high } \\
\text { light and low virus }\end{array}$ & -157 & -019 & 098 \\
\hline \multicolumn{5}{|l|}{ Run 2} \\
\hline channel I & $\begin{array}{l}\text { High turbidity, low } \\
\text { light and low virus }\end{array}$ & -243 & -009 & 100 \\
\hline channel 0 & $\begin{array}{l}\text { Low turbidity, high } \\
\text { light and low virus }\end{array}$ & -242 & -010 & 099 \\
\hline \multicolumn{5}{|l|}{ Run 3} \\
\hline channel I & $\begin{array}{l}\text { Low turbidity, high } \\
\text { light and high virus }\end{array}$ & -072 & -009 & 097 \\
\hline tray I & $\begin{array}{l}\text { Low turbidity, high } \\
\text { light and high virus }\end{array}$ & -074 & -009 & 100 \\
\hline channel 0 & $\begin{array}{l}\text { High turbidity, low light } \\
\text { and high virus }\end{array}$ & -094 & -007 & -099 \\
\hline tray 0 & $\begin{array}{l}\text { High turbidity, low light } \\
\text { and high virus }\end{array}$ & -092 & -008 & 100 \\
\hline
\end{tabular}

$* r^{2}$ is a measure of how well the data points fit the calculated slope line The $0-1 \mathrm{~h}$ slopes are all 100 since only two data points were available for calculating the slope 


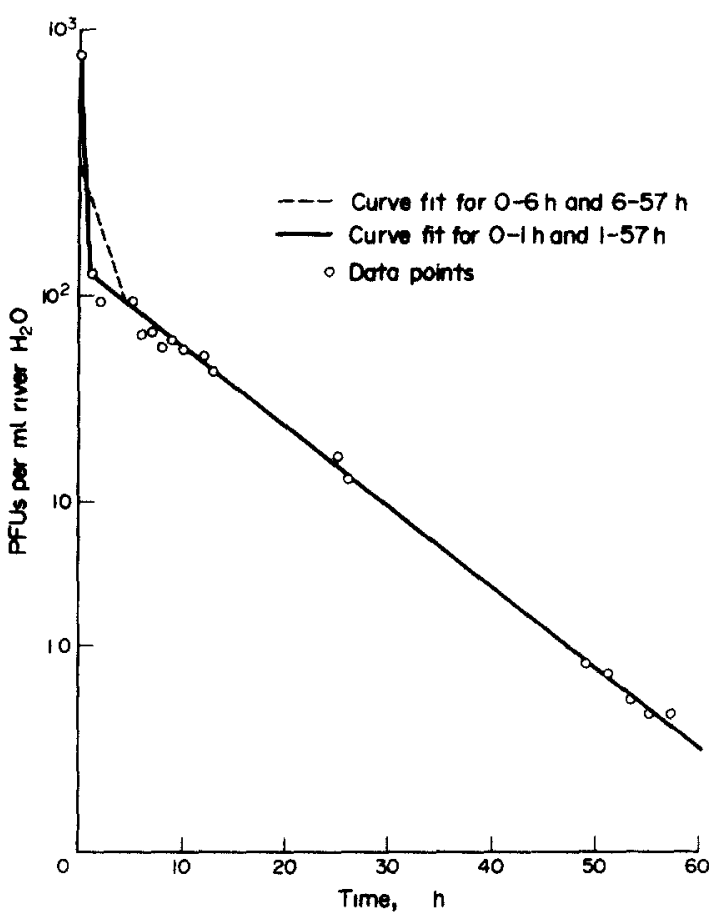

Fig 11 Channel study companson of two LOI curve intervals (high turbidity, low light and low virus level)

strength and substances which compete for the avallable bindings sites influence both adsorption and aggregation (Akın et al, 1971)

The appearance of the early component of the LOI curves suggests that the aquatic environment provided by the river water was sufficiently different from the stock virus preparation to mask the potential influence of the variables on the rate of LOI during the early portion of the experiments Thus, the influence of turbidity and light on the LOI rate became apparent only after the factor(s) responsible for the early LOI component subsided

Turbidity was implicated at the 005 significance level as a source of LOI rate varıation during the second curve component and durng the interval which included the second component and the transition period, but not during the early component The increased LOI rate associated with the higher level of turbidity suggests the possibility of solids associated infectivity and reiterates the necessity for using caution in assuming that the potential infectivity level is no higher than the assayed value (Wallis \& Melnick, 1967) The number of reported recoveries over $100 \%$, no doubt result from solids separation in the sampling process and illustrate the point and reveal the incomplete state of knowledge of the phenomena governing the behavior of enteric viruses in the aquatıc environment (Akın et al, 1971)

The effect of solar radiation has not been previously examined with regard to natural waters and enteric viruses $U V$ light has been investigated as a virucidal treatment for contaminated waters in the shellfish industry (Hill et al 1969) and the mechanisms responsible for the virucidal effects haid been examined (Kalter \& Millstem 1974, Schatuh if at 1974 Wellings et al 1974) In addition the extent and penetration of solar radiation into the aquatic environment has been investigated (Ruttner 1973) and suggests the potential for ambient solar radiation to exert a virucidal effect

As was the edse with turbidity the rapid LOI rates associated with the carly component masked the detection of any potential influence of light during that interval Data from the trays which received ambient solar radiation was also examined for evidence of a diurnal LOI pattern, with a diminished night-time LOI rate I'nfortunately the rates were so rapid that only three of the eight ambient light trays had more than one daylight slope interval betore the infectivity dropped below the detection level The diurnal slope andlysis was thus inconclusis However the statistical evaluation of slope data produced highly significant variation associated with the effects of solar radiation following the early LOI component Additional research is needed to determine if the effect is direct or as has been suggested in indirect such as enhanced biological activity

A similar acceleration in the loss of inlectuvity has been reported for viruses seeded onto vegetation v1d spray irrigation (Konowalchuck \& Spiers, 1971) The results of the current research indicate that solar radiation may be added to the list of variables which determine the infectivity of poliovirus in the aquatic environment

The mechanisms by which turbidity affects the rate of LOI needs to be further defined In natural waters, where turbidity levels may be higher and depths greater than those used in the current resedrch, the penetration of light would be diminished and hence turbidity would shade and protect virus particles from the virucidal effects of light Further research is needed to determine the impact of light in natural settings such ds impoundments with relatively clean water

Acknowledgements- This paper was taken in part from a dissertation submitted by C P Cubbage in partid fulfillment of the requirements for the $\mathrm{Ph} D$ Degree at The University of Michigan Ann Arbor

\section{REFERENCES}

Akın E W, Benton W J \& Hıll W F, Jr (1971) Enteric viruses ground and surface waters a review of their occurrence and survival and a review of methods and applications Proc 13th Wat Qual Conf Univ Illinols Bull 69, 59-74

Berg G (1976) Microbıology-detection, occurrence and removal of viruses $J$ Wat Pollut Control Fed 48 , $1410-1416$

Berg G (1977) Microbiology--detection, occurrence and removal of viruses $J$ Wat Pollut Control Fed 49. $1290-1299$ 
Bitton G (1975) Adsorption of viruses onto surfaces in soll and water Water Res 9, 473-484

Carlson G F, Jr, Woodward F C, Wentworth D F \& Sproul O J (1968) Virus inactivation on clay particles in natural waters $J$ Wat Pollut Control Fed 40. R89-R 106

Dahlıng. D R. Berg G \& Berman D (1974) BGM a continuous cell line more sensitive than primary rhesus and african green kidney cells for the recovery of viruses from water Hlth Lab $S_{C 1} 11,275-282$

DeMichele E (1974) Water reuse, virus removal and publıc health Virus Survival in Water and Wastewater Systems Edited by Malina J F, Jr \& Sagik B P Center for Research in Water Resources, Unıv Texas, Austın, Texas, pp 45-56

Fowlks W L (1959) The mechanism of the photodynamic effect $J$ invest Derm 32, 233-247

Floyd R \& Sharp D G (1977) Aggregation of poliovirus and reovirus by dilution in water Appl Microbiol 33 . $159-167$

Gannon J J , Dirasıan J A \& Phaup J D (1966) A versathle outdoor channel for water pollution investigations Proc 21st Ind Waste Conf Purdue Unıv Eng Bull 121, 234-247

Geldreich E E (1969) Water pollution microbiology $J$ Wat Pollut Control Fed 41, 1053-1069

Gerba C P \& Schaiberger G E (1975a) Aggregation as a factor in loss of viral titer in seawater Water Res 9. 567-571

Gerba C P \& Schaiberger G E (1975b) Effect of particulates on virus survival in seawater $J$ Wat Pollut Control Fed 47, 92-103

Hiatt C W (1964) Kinetics of the inactivation of viruses Bacteriol Rev 28, 150-163

Hıll W F, Jr, Akın E W, Benton W H, Mayhew C J \& Jakubowske W (1974a) Apparatus for conditioning unlımited quantities of finished waters for enteric virus detection Appl Microbiol 27, 1177-1178

Hıll W F, Jr, Akın E W, Benton W H, Mayhew C J \& Metcalf T G (1974b) Recovery of poliovirus from turbid estuarine water on microporous filters by the use of celite Appl Microbiol 27, 506-512

Hill W F, Jr, Akin E W, Benton W J \& Metcalf T J (1972) Virus in water II Evaluation of membrane cartridge filters for recovery low multuplicities of poliovirus from water Appl Microbiol 23, 880888
Hıll W F, Jr, Hamblet F E \& Benton W H (1969) Inactivation of polıovirus type 1 by the Kelly Purdy ultraviolet seawater treatment unit Appl Microbiol 17, $1-6$

Kalter S S \& Millstein C H (1974) Efficacy of methods for the detection of viruses in treated and untreated sewage Virus Survival in Water and Wastewater Systems Edited by Malına J F, Jr \& Sagık G P Center for Research in Water Resources, University of Texas Austın Texas

Konowalchuck J \& Spiers J I (1971) An evaluation of three agents for eluting adsorbed enterovirus from millpore membrane filters Can $J$ Microbıol 17, 1351-1355

Malına J F, Ranganathan K R, Sagik B P \& Moore B E (1975) Poliovirus inactivation by activated sludge $J$ Wat Pollut Control Fed 47, 2178-2183

Melnick J L \& Wenner H A (1969) Enteroviruses Diaqnostic Procedures for Viral and Rickettsial Infections Edited by Lennettee E $H$ \& Schmidt $N$ J American Public Health Association, 4th Edition, pp 529-602

Moore B E Sagik B P \& Malına J F, Jr (1975) Viral association with suspended solids Water Res 9. 197-203

Remington R D \& Schork M A (1970) Statistıcs with Applications to the Brological and Hedith Sciences Prentice Hall, New Jersey

Ruttner F (1973) Fundamentuls of Limnology 3rd Edition University of Toronto Press. Toronto

Schaub S A. Sorber C A \& Taylor G W (1974) The association of enteric viruses with natural turbidity in the aquatic environment Virus Survival $m$ Water and Wastewater Systems Edited by Malına J F, Jr \& Sagık B P Center for Research in Water Resources University of Texas, Austın, Texas pp 71-83

Wallis C, Henderson M \& Melnıck J L (1972) Enterovirus concentration on cellulose membrane Appl Microbiol 23, 476-480

Wallis C \& Melnick J L (1967) Concentration of enteroviruses on membrane filters $J$ Virol $1,472-477$

Wellings F M, Lewis A L \& Mountain C W (1974) Virus survival following wastewater spray irrigation of sandy solls Virus Survival in Water and Wastewater Si'stems Edited by Malına J F, Jr \& Sagik B P Center for Research in Water Resources University of Texas Austin. Texas pp 253-260

Young D C \& Sharp D G (1977) Polıovirus dggregates and their survival in water Appl Microbiol 33, $168 \quad 177$ 